\title{
Research on the Problems and Countermeasures of High-end Manufacturing Industry in China
}

\author{
$\mathrm{Xu}$ Jun \\ Business School \\ Jiangsu Normal University \\ Xuzhou, China \\ lmmxjxj@163.com
}

\author{
Ge Xingcheng \\ Business School \\ Jiangsu Normal University \\ Xuzhou, China \\ 2269098517@qq.com
}

\begin{abstract}
With the rapid development of science and technology and the rapid development of global economy, the international manufacturing industry is undergoing earthshaking changes. In recent years, the world's major industrial countries have drawn up the future development line according to their respective national conditions, thus promote the upgrading of the traditional manufacturing industry to high-end manufacturing industry, walk in the forefront of industrial development. Nowadays, the main task of the development of countries is how to achieve the rapid development of high-end manufacturing. This has undoubtedly become a new trend in the development of manufacturing. This paper tries to define the connotation and basic characteristics of high-end manufacturing industry, analyze the difficulties encountered in the development of high-end manufacturing industry in China, and put forward corresponding countermeasures.
\end{abstract}

Keywords-High-end manufacturing industry; Problems; Countermeasures; Innovation capacity

\section{INTRODUCTION}

The party's 19th CPC National Congress report mentioned: "accelerate the construction of manufacturing power, accelerate the development of advanced manufacturing, and promote the deep integration of the Internet, big data, artificial intelligence and the real economy." In the high-end consumption, innovation leading, green low carbon, sharing economy, modern supply chain, human capital services and other areas to cultivate new growth points and form new momentum. We will support the optimization and upgrading of traditional industries and aim at raising the level of international standards in order to promote our industry to the global value chain to the highend and cultivate a number of world-class advanced manufacturing clusters." It can be seen that our country is paying more and more attention to the development of highend manufacturing, which is the embodiment of the level of economic development of a country and the strength of its comprehensive national strength [1]. High-end manufacturing industry not only includes advanced technology industry, highend equipment manufacturing industry and some newly emerging industries, but also covers the connotation of transforming traditional manufacturing industry with advanced technology and realizing upgrading transformation of traditional manufacturing industry. Increasing investment in high-end manufacturing industry is conducive to enhance the core competitiveness of manufacturing industry, and it is of great significance for our country to transform the economic development mode and speed up the pace of our country to the manufacturing power.

However, compared with the high-end manufacturing industry in developed countries, our country's high-end manufacturing industry still needs efforts in the core technology, innovation capacity, industrial chain structure and product brand building.

Therefore, this paper tries to define the connotation of highend manufacturing industry, analyze the difficulties encountered in the development of high-end manufacturing industry in China, and put forward corresponding solutions to the difficulties.

\section{THE CONNOTATION OF HIGH-END MANUFACTURING INDUSTRY}

Up to now, there has not been a universal definition about this problem in the academia and even a clear statistical classification standard on it. Generally speaking, high-end manufacturing industry refers to the industry with high technology content, high added value and strong competitiveness. It is at the core of a certain industrial chain and is the inevitable outcome of a country or a region in the process of industrialization [2].

The connotation of high-end manufacturing can also be understood literally. It contains two layers of meaning: first, "high-end manufacturing" refers to advanced technology industry and brain industry and other emerging industries. Its aim is to point out the direction for the high-end development of manufacturing industry; the second is "the high-end manufacturing industry", which means to make full use of advanced technology and core competence to transform the traditional manufacturing industry and promote the upgrading and transformation of the traditional manufacturing industry [3].

Generally speaking, high-end manufacturing industries include computer and other electronic equipment manufacturing, transportation equipment manufacturing, electrical machinery and equipment manufacturing, chemical raw materials and chemical products manufacturing, aviation equipment manufacturing, nuclear power equipment 
manufacturing, satellite equipment manufacturing, Internet of things related equipment manufacturing, marine engineering equipment manufacturing etc.

The differences between the high-end manufacturing industry and the traditional manufacturing industry: the traditional manufacturing industry relies on the relatively backward traditional technology, which has the characteristics of low technical level, low labor efficiency, high labor intensity and so on. Most of the traditional manufacturing industries belong to labor-intensive and capital-intensive industries. Highend manufacturing industry is the use of advanced technology, equipment. And it is the transformation and upgrading of traditional manufacturing industry, with high technology content, high value-added, high competitiveness and other characteristics. The biggest distinction between the traditional manufacturing industry and the high-end manufacturing industry lies in the upgrading of the strength of science and technology. So, increasing the development of the high-end manufacturing industry is the only way to upgrade the traditional manufacturing industry [4].

\section{THE PROBLEMS WITH HIGH-END MANUFACTURING}

\section{A. Lack of core technology and insufficient innovation capacity}

Define abbreviations and acronyms the first time they are used in the text, even after they have been defined in the abstract. Abbreviations such as IEEE, SI, MKS, CGS, sc, dc, and rms do not have to be defined. Do not use abbreviations in the title or heads unless they are unavoidable. Insufficient innovation ability and lack of core technology are two important factors which restrict the development of high-end manufacturing industry in China [5]. Of the top 100 global innovators in 2016, Japan accounted for 34, second only to 39 in the United States, while only Huawei is on the list in China. In 2016, the United States topped the list of international patent applications for 39 consecutive years, with nearly 56,600 applications submitted, accounting for about $1 / 4$ of the total number of applications; Japan ranked second with about 45,000 pieces and China ranked third with a total of 43,000 pieces. Moreover, the patent applied for in the manufacturing enterprises in our country has the characteristics of low patent influence and so on. Our country's high-end manufacturing enterprises rely on foreign advanced technology, which are mainly dependent on the introduction of foreign advanced technology to produce products through the assemblage of products. The technical content and added value of the products produced are relatively low. In addition, some local manufacturing enterprises still have many problems, such as weak R \& D capability, repeated construction, repeated R \& D, limited coverage and so on. All of these have greatly affected the innovation and development of high-end manufacturing industry.

\section{B. Incomplete structure of industrial chain}

In the high-end manufacturing enterprises of our country, there is a phenomenon that the industrial chain structure of some enterprises is dispersed. Fundamentally speaking, it is due to the weak R \& D strength of some larger enterprises and the strong $\mathrm{R} \& \mathrm{D}$ strength of those large enterprises have not formed a strong industrial chain with the core of the main manufacturing plant, extending up and down. As a result, the overall scale of their industries is difficult to expand, and the economic benefits are also difficult to improve. At the same time, the lack of competitiveness is also one of the reasons leading to the fragmentation of industrial chain structure. As a typical representative of high-end manufacturing industry, there is such a problem in power equipment. Power equipment can be said to be a prominent field of independent innovation of high-end equipment in China. But its lack of competitiveness and even some key components have to rely on imports, which also leads to incomplete industrial chain phenomenon [6].

\section{Serious phenomenon of industrial isomorphism and insufficient coordination between regions}

With the development of science and technology and the improvement of roundabout production, the organizational structure of enterprises is increasing with the development of division of labor. As a result, the phenomenon of industrial isomorphism began to appear. Instead of innovating the industrial structure according to their own regional advantages, each region followed the crowd blindly, which not only led to the reduction of the efficiency of resource allocation and seriously hindered the normal development of the economy. In addition, some enterprises do not attach great importance to regional coordination and cooperation. Instead, they only take short-term interests into consideration without thinking from a long-term development. The original traditional industries have lost the best period of development as a result of blindly developing emerging industries which has caused vicious competition between enterprises. As a result, emerging industries are immature and traditional industries lose their vitality [7].

\section{Weak brand consciousness}

With the development of economic globalization, countries in the world are making more and more efforts to build their own international brands. A good international brand not only represents the name, quality and concept of this product but also represents the cultural concept of a country, plays a role in propagating its own cultural point of view, enhances communication with the world and spreading human civilization fundamentally. However, today, there are very few world brands in our country, and the competition ability is not high. This is not only due to the small number of patents obtained by Chinese enterprises, which leads to a great distinction with the big state of innovation, but also most of enterprises lack the ability of innovation and the consciousness of brand is weak. Therefore, China still has a long way to go before it can be realized from "made in China" to "create in China" [8]. 


\section{E. Low utilization of resources and serious environmental pollution}

With the progress of society, our country is worried about the problems of energy consumption and environmental pollution brought by the continuous development of manufacturing industry. It is mainly the industry with high energy consumption and high pollution. It has the characteristics of low utilization of resources and high emission intensity etc. Especially in recent years, the phenomenon of industrial isomorphism in manufacturing industry has led to a large number of waste of resources and the decline of environmental carrying capacity and other serious consequences. In recent years, although the energy consumption per unit GDP in our country has decreased, there is still a distinction compared with some developed countries. Industrial wastewater, sulfur dioxide and soot produced in industrial production are the main pollutants of environmental pollution, which destroy the ecological balance of nature seriously. Nowadays, haze, water pollution and soil heavy metal pollution has become a social hazard. The low efficiency of resource and energy utilization and the problem of environmental pollution have become an important factor, which restrict the sustainable development of our country's economy. The transformation and upgrading of manufacturing industry is faced with unprecedented resources and environmental pressures and challenges.

\section{RESEARCH ON THE COUNTERMEASURES OF HIGH-END MANUFACTURING INDUSTRY IN CHINA}

A. The countermeasures of high-end manufacturing industry from the national level

- Develop and implement upscale manufacturing training programs. On the one hand, our country can follow the trend of the development of high-end manufacturing industry. At the same time, we can focus on the "made in 2025"program, which is put forward by our country. It is adhering to the basic guidelines of "innovationdriven, quality first, green development, structural optimization and talent-oriented" and adhering to the basic principles of "market-driven, government-led; based on the current, long-term perspective; overall progress; key breakthroughs; independent development and open cooperation". We will realize the strategic goal of powerful manufacturing country through three steps.

- Support research and development of the industrial basic common technology and construction of network system. Many technologies in high-end manufacturing industry play a key role in economic development. To a large extent, these technologies affect the drive and integration of downstream industry and economy. This indicates that the research and development of high-end manufacturing industry had better infiltrate from the downstream industries and do the high-end manufacturing industries with industry commonalities, key, forward-looking equipment technology. At the same time, the dominant government should do all it can to pool industry-university-research's strengths for joint development. Therefore, the R \& D team should be constructed so that the technology is always in the forefront and the technological advantage should be formed [9].

- Build international advanced industrial bases and industrial clusters. Practice shows that industrial accumulation, which can strengthen the industrial division of labor, reduce innovation costs and optimize the allocation of production factors, is an important way to improve the competitiveness of industry. In the process of development of China's manufacturing industry, the government should concentrate its efforts on developing a number of industrial bases and industrial clusters with international advanced levels, in accordance with the principles of rational layout, distinctive characteristics, intensive land use, and ecological environmental protection. We will guide and promote the concentration of related industries into industrial parks actively; strengthen the construction of industrial clusters linked by industrial chains; further promote the development of industrial accumulation; land use, intensive use of resources and centralized control of pollution. We will strive to cultivate a group of high-end manufacturing industrial bases and industrial clusters with obvious advantages in terms of independent innovation, brand quality, energy conservation and emission reduction, and service system construction.

\section{B. The countermeasures of high-end manufacturing industry} from the enterprise level

- Enhance the innovation ability and core technology of high-end manufacturing enterprises. While learning advanced technology in the world, enterprises should improve their own independent innovation ability, so as to achieve the purpose of innovation to promote product upgrading. It is necessary to selectively introduce, digest, and absorb foreign advanced talents, management systems, and excellent manufacturing technologies and processes by means of joint ventures and mergers. At the same time, enterprises should also increase the investment in scientific research, have their own core technology, form the core competitiveness, and be able to occupy the leading position in the international high-end manufacturing competition. The system of technological innovation with enterprise as the main body, market as the guide and industryuniversity-research as the combination is gradually established, so that the institutional framework of independent innovation can be formed easily [10].

- Construct open innovation network system. If high-end manufacturing enterprises want to improve their independent innovation ability, they should build open innovation network and use the mentality of openness and tolerance actively. Enterprises strengthen the global collaborative innovation cooperation with customers, suppliers, competitors, scientific research institutions and universities, and fully integrate all kinds of innovation resources and make the best use of them. 
Because open innovation has the characteristics of network, it emphasizes the integration and utilization of innovation resources inside and outside the enterprise. In addition, high-end manufacturing enterprises should attach importance to the cooperation with the region to achieve the goal of win-win, so as to establish a common development base with regional cooperation. In the era of economic globalization, with innovation resources in the global flowing and allocation further deepening, high-end manufacturing enterprises should explore the current situation of economic development in various regions, make full use of incentive policies. We should encourage enterprises in all regions to develop high-end manufacturing industries vigorously so as to achieve common development in all regions.

- Strengthen the ability of brand building. Brand is the soul of an enterprise which plays a key and leading role. Modern enterprises have brought brand cultivation into their operation system. High-end manufacturing enterprises should enhance the added value of their products by strengthening their brand building capacity and establishing and deepening the market influence of their products [11]. Implement the brand strategy. While consolidating and developing old brands, enterprises should speed up the mastery of core technologies and strengthen the learning of foreign well-known brands with independent intellectual property rights. Enterprises should put forward the corresponding measures to strengthen the brand construction of high-end manufacturing industry and formulate the relevant incentive policies. In addition, they should give some encouragement and support in technological innovation and R \& D investment; guide the advanced resources to the famous brand enterprises actively. We provide a solid brand cultivation platform, establish and improve the brand service system based on brand establishment, publicity, consultation and recommendation so as to enhance the brand gestation ability of China's higher manufacturing industry.

- Attach great importance to green manufacturing and realize sustainable development of economy and society. We should solve the problems of resource and energy consumption and environmental pollution caused by manufacturing, and realize the sustainable development of economy and society. On the one hand, green manufacturing, cleaner production, recycling economy, low-carbon economy and other advanced concepts should be applied to all aspects of the manufacturing industry. On the other hand, we should actively promote the "three transformation" of the manufacturing industry: intensification, circulation, low carbonization. We are supposed to improve the resource utilization efficiency of manufacturing industry; accelerate the development of green manufacturing industry. So our country's industrial economy will continue to develop healthily and green.

\section{CONCLUSIONS}

This paper tries to define the connotation of high-end manufacturing industry, and analyze the difficulties encountered in the development of high-end manufacturing industry in China including the lack of core technology and innovation ability, incomplete industrial chain structure, industrial isomorphism, insufficient regional coordination and weak brand awareness. And it puts forward solutions to the plight of high-end manufacturing from the national level and enterprise level.

\section{ACKNOWLEDGMENT}

This research was financially supported by National Social Science Foundation (Grant No. 16BJY042).

\section{REFERENCES}

[1] Jiang Hong.Discussion on the development path of high-level manufacturing industry in China-- a case study of Qingdao [J]. Enterprise Economy, 2014(5):106-109.

[2] Liu Yang. Strategic orientation of the development of high-level manufacturing industry in China [J]. Productivity Study:92-94.

[3] Gao Qingyu. Study on Tianjin's strategy of building high altitude of high-level manufacturing industry[D]. Tianjin:Tianjin University,2010.

[4] Anil Mitala,Arunkumar Pennathur. Advanced technologies and humans in manufacturing workplaces:an interdependent relationship [J]. International Journal of Industrial Ergonomics,2004(33), 295-313.

[5] Zhou Ye, Han Chunli. Research on the development of high-level manufacturing industry in China [J]. Industrial Economy: 27-31.

[6] Lu Yongquan. A study on the development of high-level equipment manufacturing industry in China $[\mathrm{J}]$. Economic and Social Development,2015,13(3):1-4.

[7] Niu Shihua. The problems of the development of China's manufacturing industry and the way to solve it $[\mathrm{J}]$. Modern Commerce and Industry 2007,19(7):5-6.

[8] Yang Shengnan.Analysis of foreign capital control of high-end manufacturing industry in China[D]. Beijing: Beijing Jiaotong University, 2014.

[9] Han Song. Dilemma and breakthrough of China's advanced manufacturing Industry[J]. Business Managers,2017(3):199.

[10] Zhang Junyi. Evaluation of independent innovation ability of high-level manufacturing enterprises [D]. Harbin: Harbin Engineering University, 2013.

[11] Peng Zhenzhen. A brief discussion on the development of high-level equipment manufacturing industry in China [J].Modern Economic Information, 2014,4(1):328. 